\title{
Black workers, typhoid fever and the construction of the Berg River - Saldanha military water pipeline, 1942 - 1943
}

\author{
GE VISSER AND FL MONAMA*
}

\begin{abstract}
War creates a huge need for labour to support the war efforts of the belligerent parties. In South Africa tens of thousands of 'non-white' workers were mobilised during the Second World War to satisfy the Union Defence Force's (UDF's) labour needs at home and abroad. This article, firstly, outlines the role of 'non-white people', particularly black Africans, in the UDF with special reference to those employed within the Union of South Africa. Secondly, it briefly delineates typhoid fever as an historical thorn in the flesh of military forces up to the early $20^{\text {th }}$ century. It then looks briefly into the incidence of and perceptions on typhoid fever as a killer disease in South Africa on the eve of the Second World War. Against that background, the article investigates the employment of black workers on the construction of the Berg River-Saldanha Bay military water pipeline and the UDF's response to the threat and subsequent outbreak of typhoid fever amongst the workers at the Berg River intake site in 1943. The article concludes that the public health authorities and UDF were aware of the threat of typhoid fever with regard to the Berg River water scheme, but did not take sufficient precautionary measures, which could have had serious repercussions for the Allied war effort. This incident should serve as a warning to the South African National Defence Force when deploying on peace support operations on the African continent where typhoid fever remains a serious threat next to Hiv/Aids.
\end{abstract}

Keywords: Water, history, military, Saldanha, Berg River, typhoid fever, pipeline, Second World War, black workers, Union Defence Force.

Disciplines: Military history, medical history, social history

* Lieutenant Colonel GE (Deon) Visser is an associate professor of Military History at the Faculty of Military Science, Stellenbosch University (South African Military Academy). Mr FL (Fankie) Monama is a lecturer in Military History at the same institution. The authors are indebted to Dr Indira Govender of SAS Saldanha Sickbay for her comments.

TD: The Journal for Transdisciplinary Research in Southern Africa, Vol. 4 no. 1, July 2008, pp. 181-208. 


\section{Introduction}

War creates a huge need for labour to support the war efforts of the belligerent parties, both in the various theatres of war and at the home front, be it to erect fortifications, transport military equipment and supplies, manufacture war materials or creating infrastructure. In South Africa tens of thousands of blacks, so-called coloureds and Asians (Indian-Malay) were mobilised in and out of uniform during the Second World War (1939-1945) to satisfy the Union Defence Force's (UDF's) labour needs. The aim of this article is to determine the causes, course, and consequences of the outbreak of typhoid fever amongst the UDF's black workers at the Berg River pump station in 1943 against the backdrop of the historical threat of that disease to the military, as well as the working conditions of the UDF's black workers during the Second World War. The article, firstly, outlines the role and circumstances of 'non-white' people, particularly black Africans, in the UDF with special reference to those employed within the Union of South Africa as civilian workers. Secondly, it briefly looks into the incidence of and perceptions on typhoid fever as a killer disease in South Africa on the eve of the Second World War and the way in which the UDF dealt with the threat of the disease amongst its black workers. Against that background, the article investigates the employment of black workers on the construction of the Berg River-Saldanha Bay military water pipeline and evaluates the UDF's response to the threat and subsequent outbreak of typhoid fever amongst its black workers at the Berg River intake site in May 1943. In conclusion, the article seeks to indicate the relevance of the Berg River incident to the South African National Defence Force (SANDF) when deploying on peace support missions on the African continent.

\section{The role of black South African workers in World War II}

The South African Defence Act of 1912 had entrenched racial discrimination in the military as it stipulated that the liability to render military service in peace and war 'shall not be enforced against persons not of European descent unless and until Parliament shall by resolution determine the extent to which and conditions under which any such liability shall be enforced against such persons. ${ }^{1}$ It stipulated further, however, that nothing would prevent 'the voluntary engagement at any time of such persons for service in any portion of the Defence Forces in such capacities and under such conditions as are prescribed'. ${ }^{2}$ In practice, this meant that blacks, so-called

1 Union of South Africa, South Africa Defence Act.

2 Ibid. 
coloureds and Asians (Indian-Malay) were destined for inferior roles, being allowed to sign up for tedious supportive and unskilled roles only, both in uniform and as civilians. Thousands of these people of colour served as construction and other workers, guards, drivers, stretcher-bearers, cooks, orderlies, clerks and similar, non-combatant roles during the Second World War. ${ }^{3}$

Three 'Non-European' military units, namely the Native Military Corps, the Cape Corps (comprising of so-called 'coloureds') and the IndianMalay Corps were raised in the Union during the Second World War through the agency of the Native Affairs Department and the Directorate Non-European Army Services. ${ }^{4}$ The mobilisation and recruitment of 'Non-Europeans', particularly blacks, was riddled with controversies premised on paternalistic and racial prejudice which drove policy decisions in the country. Firstly, the question of blacks taking part in a 'white men's war' and secondly, the issue of them carrying 'precision arms' produced negative reactions from the majority of whites. ${ }^{5}$ The military authorities, taking cognisance of the practicalities of the war, knew that it made sense to recruit from the black population because whites were in a minority and inevitably their military expertise would be immediately needed in combat zones at the frontlines. And, a significant part of the white population, particularly the Afrikaans-speaking section, refused to participate in the war. However, the political implications of even arming blacks were too great; hence the 'compromise' of recruiting blacks to serve mostly in inferior roles as labourers, and not as combat soldiers. South African Prime Minister, General J.C. Smuts, made the position of blacks that actually served in uniform clear in 1940 when he stated that

in order to forestall misrepresentation and prevent possible misunderstanding, it is to be clearly understood that natives will not $\ldots$ be equipped with arms of precision. ${ }^{6}$

Another factor related to the recruitment of blacks was the question of the adequacy of the available labour pool. The 1936 census put the black male population of the Union between the ages of 18 and 45 at 1539 758, which, according to Grundlingh, had risen to about

3 I. Gleeson, The Unknown Force: Black, Indian and Coloured Soldiers Through Two World Wars (Ashanti, Rivonia, 1994), p ix.

4 See L.W.F. Grundlingh, The Participation of the South African Blacks in the Second World War (D. Litt. et Phil. Thesis, RAU, 1986), and I Gleeson, The Unknown Force.

5 L.W.F. Grundlingh, The Participation of South African Blacks in the Second World War, pp 18-20.

6 As quoted in Grundlingh, The Participation of South African Blacks in the Second World War, p 23. 
1600000 at the outbreak of the Second World War. ${ }^{7}$ Agriculture and industry employed about 1000000 men, leaving some 600000 that could be mobilised for military service. ${ }^{8}$ It was, furthermore, estimated that about 4000 - 5000 male urban blacks in Johannesburg alone were unemployed and many others who were reluctant to be employed in mine or on farms, could be available for recruitment. Although the objective number of blacks to be recruited vacillated with changing fortunes of the Allied forces, approximately 80000 ultimately served during the war in uniform or as civilian workers. The majority of these men came from rural South Africa, contrary to the "interests" of the authorities who preferred urban blacks because of their experiences in skilled employment such as construction, industries and mines, as well as some degree of literacy. Hence the first recruiting initiatives targeted township beer halls, eating halls, cinemas, clubs, schools, trams, buses and trains. ${ }^{9}$ However, after the fall of Tobruk in June 1942, recruitment procedures were reorganised to draw more people from the rural areas where the local chiefs were used as agents. ${ }^{10}$

Most of the black men who found employment as civilian labourers in the UDF, like their compatriots in uniform, were compelled by lack of job opportunities in the urban areas and poor economic conditions in the rural areas resulting from droughts and other natural disasters such as 'army worms'. Poor health amongst some of these men could be ascribed to structural factors such as poor socio-economic conditions and lack of access to adequate health care facilities. Compounding this problem was the conditions under which blacks lived and worked in the UDF. ${ }^{11}$

The service conditions of black workers in the UDF, as in other employment sectors in the Union, were poor. Compared to white people, their wages were extremely low, while their food and accommodation was of poor quality. Blacks were fed on dry bread at times, and due to the lack of appropriate cooking facilities and messes

7 L.W.F.Grundlingh, The Participation of South African Blacks in the Second World War, pp 23, 54 .

8 Ibid.

9 South African National Defence Force Archives (hereafter SANDFA), NMC 5, NAS3/ 4/20/1, 'Native Military Corps Recruiting: Progress Report for period 10/1/43 to $23 / 1 / 43$.

10 Ibid.

11 L.W.F. Grundlingh, The Participation of South African Blacks in the Second World War, p 138; M. Roth, "If you give us rights we will fight": Black Involvement in the Second World War, South African Historical Journal (No. 15), November 1983, pp 85-104. This article highlights some of the laborious non-military tasks such as mining salt, carting maize and extracting rubber, which were performed by the Native Military Corps in adverse conditions inside the Union and they were also exposed to diseases such as malaria. 
as opposed to whites, they were sometimes forced to cook and eat out in the open. ${ }^{12}$ The accommodation comprised in most cases of mining compounds, bungalows and tents. ${ }^{13}$ Grundlingh paints a dreadful picture of the abysmal conditions for blacks in various military camps. At the Congella camp, for example, open timber sheds were closed with corrugated iron with no doors, windows or floors. ${ }^{14}$ The tents for blacks were poorly sited as they were either flooded during rainy seasons or too dusty in dry periods, resulting in extreme health hazards. The whites, on the other hand, had weatherproof tents. The black camps were also overcrowded, while in some cases servicemen slept on concrete floors; the roofs were leaking; ablution and sanitary facilities were in a poor state, sometimes with no running water. ${ }^{15}$ Hence, under these circumstances, hygiene was massively perilous, creating favourable conditions for a plethora of diseases, including typhoid fever.

\section{Typhoid fever: the 'poor man's burden' and the soldier's deadly companion}

Enteric fever, specifically Typhoid fever, the 'typical form of enteric fever ${ }^{16}{ }^{16}$ has historically been a great destroyer of human life and it is estimated that even today, despite huge advances in health care globally, up to 22 million people contract the disease worldwide every year, of whom about 200000 die. Typhoid fever is defined as an 'acute infectious disease caused by a specific serotype of the bacterium Salmonella typhi. ${ }^{17}$ This bacterium lives in humans only and enters the body through the mouth by the intake of contaminated food or water. It penetrates the intestinal wall and multiplies in lymphoid tissue, entering into the bloodstream within 24 to 72 hours after infection, causing septicaemia (blood poisoning) and systemic infection. The early symptoms of typhoid are headache, malaise, generalized aching, fever and restlessness, which appear after an incubation period of ten to fourteen days. Patients may also experience a loss of appetite, nosebleeding, coughing and diarrhoea or constipation. They develop a persistent, gradually rising fever peaking at about $40^{\circ} \mathrm{C}$ and after about two weeks of fever, serious complications such as internal bleeding, acute inflammation of the

12 L.W.F. Grundlingh, The participation of South African Blacks in the Second World War, p 138.

13 Ibid, p 139.

14 Ibid.

15 Ibid.

16 P. Kumar and M. Clark, Clinical Medicine, 5th ed (WB Saunders, Edinburgh, etc, 2002), p 88.

17 Encyclopædia Britannica, “Typhoid fever", Encyclopaedia Britannica 2008 Ultimate Reference Suite (Encyclopædia Britannica, Chicago, 2009). 
gallbladder, heart failure, pneumonia, osteomyelitis, encephalitis, and meningitis may develop. Continued high fever may also lead to mental confusion and delirium. The fever normally starts declining, in favourable cases, by about the fourth week, whereupon the symptoms begin to abate. Without treatment, the sickness thus lasts for three to four weeks and between 12 and 30 per cent of those infected will die, while about 10 per cent of the survivors will have relapses. Infected people carry the bacteria in their bloodstream and intestinal tract. About 5-10 per cent of people who recover from typhoid fever, called carriers, continue to shed Salmonella typhi in their faeces for several months and 1-4 per cent continue to carry the organism for more than a year. Antimicrobial treatment shortens the duration of the illness and reduces fatalities. ${ }^{18}$

Most epidemical outbreaks of typhoid are normally the result of the public water supply or drinking water being polluted by human excreta. This killer disease therefore affects mostly vulnerable groups of overcrowded, poverty-stricken communities, especially in the developing world, because outbreaks are facilitated by poor socioeconomic conditions where hygiene is generally low, handwashing is infrequent and ineffective sanitation systems often result in the contamination of drinking water with raw sewage. ${ }^{19}$ An outbreak can of course also result from food and milk being contaminated by a carrier of the disease who is involved the in handling and processing such commodities. Second to human contact in spreading typhoid, are house flies in a situation where there is 'an abundance of flybreeding material' and the flies have access to typhoid-infected human faeces. ${ }^{20}$ Other possible causes are contaminated dust, fresh vegetables grown on soil fertilized or polluted by raw sewage and the use of polluted water for cleaning purposes. ${ }^{21}$ Outbreaks of typhoid fever are consequently best prevented through proper sewage

18 P. Kumar and M. Clark, Clinical Medicine, 5th ed (WB Saunders, Edinburgh, etc, 2002), p 88; Encyclopædia Britannica, "Typhoid fever", Encyclopaedia Britannica 2008 Ultimate Reference Suite (Encyclopædia Britannica, Chicago, 2009); http:// www.cdc.gov/ncidod/dbmd/diseaseinfo/typhoidfever_g.htm, accessed 6 July 2007; http://www.cdc.gov/ncidod/dbmd/diseaseinfo/typhoidfever t.htm, accessed 6 July 2007; http://wwwn.cdc.gov/travel/yellowBookCh4Typhoid.aspx, accessed 6 July 2007.

19 http://www.cdc.gov/ncidod/dbmd/diseaseinfo/typhoidfever_g.htm, accessed 6 July 2007; http://www.cdc.gov/ncidod/dbmd/diseaseinfo/typhoidfever_t.htm, accessed 6 July 2007; http://wwwn.cdc.gov/travel/yellowBookCh4Typhoid.aspx, accessed 6 July 2007; P. Kumar and M. Clark, Clinical Medicine, p 88.

20 See V.J. Cirillo, “'Winged Sponges': Houseflies as Carriers of Typhoid Fever in 19th- and Early 20th-Century Military Camps", Perspectives in Biology and Medicine 49 (1), Winter 2006, pp 52 - 63.

21 Encyclopædia Britannica, "Typhoid fever", Encyclopaedia Britannica 2008 Ultimate Reference Suite (Encyclopædia Britannica, Chicago, 2009). 
treatment, filtration and chlorination of water and the exclusion of carriers from employment in the food industry and restaurants. Prophylactic vaccination was introduced in the early $20^{\text {th }}$ century, but none of the available vaccines is completely effective. ${ }^{22}$

Typhoid fever was one of the $19^{\text {th }}$ century's deadliest diseases, especially in densely populated urban areas. As a killer disease, it was in a sense comparable to the situation with regard to HIV/Aids today, if not in terms of incidence, then at least in terms of the fear factor regarding public health. ${ }^{23}$ Although it declined with the improvement of urban sanitation systems, it remained a considerable public health threat. ${ }^{24}$ War always produce 'high risk situations ${ }^{25}$ which accelerates 'spatial transmission and rate of [epidemic disease] propagation'26 because of the prevalence of mixing of various groups from different backgrounds. The huge concentration of people and the frequent absence of adequate sanitation and water purification measures in the field during military campaigns made armies also particularly vulnerable to typhoid fever. It is thus no great surprise that when prophylactic vaccination against typhoid fever was first introduced at the beginning of the $20^{\text {th }}$ century, it was primarily in military forces and institutions. ${ }^{27}$ Disease had, as Gabriel and Metz put it,

ever since the dawn of warfare... carried off more soldiers than enemy weapons... [and] more combat power was lost to armies by temporary disablement due to illness than to any other cause. ${ }^{28}$

John Keegan observes that in earlier times

the threat of epidemic disease accompanied armies wherever they moved, and the outbreak of disease - cholera, dysentery, typhoid, plague - remained the greatest killer of soldiers until the very recent past. Armies acted also as principal disease carriers, and their pestilence was one of the reasons why settled peoples so often fled their homes when an army passed by or, more menacingly, pitched camp. Armies that campaigned across disease

22 Ibid

23 J.W. Leavitt, Typhoid Mary: Captive to the Public's Health (Beacon Press, Boston, 1996), pp 2, 4, 21.

24 J.W. Leavitt, Typhoid Mary: Captive to the Public's Health (Beacon Press, Boston, 1996), pp 9, 21.

25 S. Marks, "An Epidemic Waiting to Happen? The Spread of HIV/AIDS in South Africa in Social and Historical Perspective, African Studies, 62 (1), 2002, pp 14$15,17$.

26 M. Smallman-Raynor and A.D. Cliff, "The spatial dynamics of epidemic diseases in war and peace: Cuba and the insurrection against Spain, 1895-98", Transactions of the Institute of British Geographers 24 (3), pp 331-352.

27 Encyclopædia Britannica, "Typhoid fever".

28 R.A. Gabriel and K.S. Metz, A History of Military Medicine II: From the Renaissance through Modern Times (Greenwood Press, New York, etc, 1992), p 66. 
barriers... exposed themselves to sicknesses against which they had acquired no immunity; they might equally carry with them the agents of disease that would destroy a local population without firing a shot in anger. ${ }^{29}$

Typhoid fever, dubbed by Cirillo 'the scourge of $19^{\text {th }}$ - and $20^{\text {th }}$-century armies'30 always took a heavy toll on military campaigns. Besides human contact, flies contributed greatly to this state of affairs. Horses played a critical role in the armies of the day and the ever-present piles of horse manure in military camps provided excellent flybreeding sites, while pit latrines afforded the flies a rich source of typhoid-infected human faeces. ${ }^{31}$ Sir William Osler, Regius Professor of Medicine at Oxford University, stated in July 1916:

(T)yphoid fever... in nearly every great war had been an enemy as formidable as the bullet... it was above all other diseases the most fatal...an insidious enemy which... sapped the strength of the opposing forces... Over and over again it killed thousands of soldiers before they ever reached the firing line, while the deaths at the front were appalling. ${ }^{32}$

Osler substantiated his claim with statistics from a few well-known wars from the late-nineteenth to the early-twentieth century. He pointed out that during the American Civil War (1861 - 1865), statistically 'the most life-threatening war ever fought'33 and in which three of every five Union deaths (and two of every three Confederate deaths) resulted from disease, ${ }^{34}$ the Union Army alone suffered 79455 cases of typhoid, of whom 29336 died. Subsequent research revealed even more staggering figures. Cirillo claims that the Union army, out of mean strength of 1,5 million men, suffered 136862 cases of typhoid of whom 34696 (25,3 per cent) died. ${ }^{35}$ In the Franco Prussian War (1870 - 1871) some 8000 Prussian soldiers died of typhoid fever, representing 60 per cent of all their war deaths. During the Spanish-American War (1898) 20738 out of 107073 American soldiers, almost $20 \%$, contracted typhoid, of whom 1380 died - all within six months (June - November). In the Second Anglo-Boer War (1899 1902) the British, who deployed close to 500000 troops in

29 J. Keegan "Foreword" in R.A. Gabriel and K.S. Metz, A History of Military Medicine II, pp xi-xii.

30 V.J. Cirillo, “'Winged Sponges': Houseflies as Carriers of Typhoid Fever”, p 53.

$31 \mathrm{Ibid}, \mathrm{p} 54$.

32 Quoted in anon., "Osler Finds Nerves Chief War Problem: Typhoid Virtually Conquered Through the Lessons Learned in Other Great Conflicts", The New York Times, 9 Julie 1916 . (http://query.nytimes.com/gst/ abstract.html? res=9E04E0DF1E31E733A0575AC0A9619C946796D6CF, accessed 16 January 2008.)

33 R.A. Gabriel and K.S. Metz, A History of Military Medicine II, p 181.

34 Ibid.

35 V.J. Cirillo, “'Winged Sponges': Houseflies as Carriers of Typhoid Fever”, p 53. 
South Africa, suffered 57684 cases of typhoid, of which 19454 were invalided and 8022 died. ${ }^{36}$ 'More British soldiers, Osler claims, 'were lost from the bacilli of typhoid than from the bullets of the Boers', ${ }^{37}$ which is not altogether an exaggeration, since a mere 5774 British soldiers were killed in action, but one must add to that number just over 2000 that died of wounds. ${ }^{38}$

Typhoid fever was indeed endemic in many parts of South Africa at the time of the Anglo-Boer War. ${ }^{39}$ It certainly caused many casualties amongst the Boer commandos, but what stands out in South Africans' memory, is how, in the much-quoted words of then British Liberal Party leader, Sir Henry Campbell-Bannerman, British 'methods of barbarism'40, negligence and indifference cost tens of thousands of South Africans' lives, black and white, most of them women and children, in Lord Kitchener's infamous concentration camps. The majority of these deaths resulted from 'epidemics of measles and typhoid that could have been avoided' ${ }^{41}$ In the white concentration camp at Heilbron alone there were some 400 deaths a month by November 1901 of which a large percentage were caused by typhoid. ${ }^{42}$ The situation was probably worse in black concentration camps given the prevailing socio-structural and political conditions, but due to poor British recordkeeping and the neglect of that aspect of the history of the Anglo-Boer War, very little information is available for evaluation. ${ }^{43}$

The Russo-Japanese War of 1904 - 1905 was the first major war in history in which more soldiers were killed by military action than by disease. ${ }^{44}$ It was also during that war that medical personnel,

36 Anon., "Osler Finds Nerves Chief War Problem: Typhoid Virtually Conquered"; See also V.J. Cirillo, “'Winged Sponges': Houseflies as Carriers of Typhoid Fever”, p 53. (Cirillo puts the mean strength of the US forces during the SpanishAmerican War at 274717 men, concurs with the figure of 20738 cases of typhoid, but claims that 1590 of them died as opposed to the 1380 mentioned by Osler.)

37 Quoted in anon., "Osler Finds Nerves Chief War Problem: Typhoid Virtually Conquered".

38 T. Pakenham, The Boer War (Abacus, London, 1992), p 572; R.A. Gabriel and K.S. Metz, A History of Military Medicine II, p 223. (According to Pakenham the total British casualties amounted to some 22000 men, of which 5774 were killed in action and 16168 died of wounds and disease. Gabriel and Metz put the number of British killed in action at 6000 and those killed by disease at 14000 .)

39 T. Pakenham, The Boer War, pp 381-2, 149.

40 Ibid, pp 504, 508.

41 Ibid, p 518.

42 Ibid, p 516.

43 T. Pakenham, The Boer War, pp 510-18; 554, 573; P. Warwick, Black People and the South African War, 1899 - 1902 (Longman, London and Ravan, Johannesburg, 1983), pp 149-51.

44 R.A. Gabriel and K.S. Metz, A History of Military Medicine II, p 226. 
especially on the Japanese side, started making significant progress in combating typhoid through a system of adequate sanitation and the experimental inoculation of troops. The Japanese achievements in military medicine indeed ricochet around the globe and medical officers from the Western world hurried off to Japan to share in their knowledge. ${ }^{45}$ The Japanese progress was supported by work done by the US Army, who created a Typhoid Board ${ }^{46}$ during the SpanishAmerican War and also experimented with the inoculation of soldiers. ${ }^{47}$

These successes enabled armed forces to combat the disease effectively right from the commencement of the First World War by inoculating soldiers before they were sent to war. Even though inoculation was not compulsory in the British army and a small minority of soldiers did not take that precaution, only 46 cases of typhoid was reported in the British forces in France and England over a period of one year in 1915/16. ${ }^{48}$

The German forces on the Western Front were equally successful in fighting the disease, ${ }^{49}$ but the French medical services were poor and they suffered 50000 cases of typhoid during the first three years of the war; almost all their water supplies were contaminated by typhoid. ${ }^{50}$ On the Eastern Front medical care was even worse than in the French Army and a high incidence of typhoid fever prevailed amongst the Russian forces, as well as amongst forces in AustriaHungary, Turkey and Asia. ${ }^{51}$

Given the high incidence of typhoid in cases where proper preventive measure were lacking, Osler correctly warned in 1916, that it still
'require[d] constant work to protect enormous armies from the ravages of typhus... the ease with which the typhoid germ may spread through a camp necessitates constant watch. A soldier on active service may take typhoid with him, or he may contract it in the country. In a large body of men there will always be a certain percentage "carriers" who may act as a focus of distribution... [and] unless strict vigilance were observed... not alone in the use of preventive serum... but in applying every precaution... to keep camps and trenches clear of germ life... the percentage of mortality would be stupendous'. ${ }^{52}$

45 Ibid; Anon., "Osler Finds Nerves Chief War Problem: Typhoid Virtually Conquered". 46 V.J. Cirillo, “'Winged Sponges': Houseflies as Carriers of Typhoid Fever”, p 53. 47 Anon., "Osler Finds Nerves Chief War Problem: Typhoid Virtually Conquered". 48 Ibid.

49 R.A. Gabriel and K.S. Metz, A History of Military Medicine II, p 244; Anon., "Osler Finds Nerves Chief War Problem: Typhoid Virtually Conquered".

50 R.A. Gabriel and K.S. Metz, A History of Military Medicine II, p 245.

51 Ibid, p 226; Anon., "Osler Finds Nerves Chief War Problem: Typhoid Virtually Conquered".

52 Quoted in anon., "Osler Finds Nerves Chief War Problem: Typhoid Virtually Conquered". 
Thus, despite the astounding successes in reducing typhoid to ' $\mathrm{a}$ negligible factor', it remains a threat to armed forces to this day if proper countermeasures are not in place.

Amongst the twenty most prominent infectious diseases, including pulmonary tuberculosis, diphtheria, scarlet fever and influenzal pneumonia, typhoid fever was still a comparatively prevalent and much-feared disease in South Africa by the outbreak of the Second World War. ${ }^{53}$ In 1928, Dr James Alexander Mitchell, the Secretary for Public Health published a circular titled, 'Catechism about Typhoid or Enteric Fever', to each local authority and magistrate in the Union to advice them on the prevalence and deadliness of the disease as well as measures to contain it. ${ }^{54}$

This circular derived from the publication of the South African Red Cross Society, 'Typhoid or Enteric Fever', with the approval of the Union Department of Public Health, to highlight the causes, spread and prevention of this disease in South Africa. ${ }^{55}$ Emphasis was placed on the so-called 'Three F's - Fingers, Flies and Filth', as the key agents in the causes and spread of typhoid fever and how these could be contained. ${ }^{56}$

Over a 16-year period up to 1939, some 3000 cases of typhoid fever had been treated in Pretoria alone, ${ }^{57}$ and in the nearby mining town of Benoni the incidence rate was 1,03 cases (all races) per thousand of the population in 1937. Four European children and 11 nonEuropeans died of the disease in Benoni in 1937. ${ }^{58}$ Given the fact that typhoid fever was not a notifiable disease, ${ }^{59}$ and black people often did not have ready access to medical services, many more could have died from the disease; countrywide the numbers over that period could have been quite significant. From August 1939 to July 1946,

53 Pulmonary Tuberculosis was the highest killer with about 100-130 cases reported monthly in Cape Town alone. Other diseases included Diphtheria (20-30 cases), Scarlet Fever (20), Cerebrospinal Fever (10-20), and Influenzal Pneumonia (2040). National Archives of South Africa, Cape Town (hereafter NASAC), 3/CT, 1 / 4/7/5/1/3 - 1/4/7/6/1/6, Public Health Committee Minutes, 1939-1946.

54 NASAC, 3/CT, 4/1/5/553, E1451/5, J. A. Mitchell, Secretary for Public Health, pamphlet no. 365 (Health), circular no. 8 of 1928, 7 August 1928.

55 NASAC, 1/UTA, 6/1/17, 13/3/6 (old no, 13/8/3), South African Red Cross Society-Union Department of Public Health. This document was available at the end of the Second World War, 21 December 1945.

56 Ibid.

57 Anon., "Carrier Problem in Eradicating Typhoid: Doctor Blames Small Townships and Native Hygiene", Rand Daily Mail, 25 May 1939. (National Archives of South Africa (hereafter NASA), NTS 6716, 27/315 II, press cutting.)

58 Anon., "Rural Natives Bring in Enteric", Rand Daily Mail, 15 August 1938. (NASA, NTS $6716,27 / 315 \mathrm{I}$, press cutting.)

59 Anon., "Rural Natives Bring in Enteric". 
the Public Heath Committee in Cape Town reported no less than 886 cases of typhoid fever (all races) in the city and Langa Township. ${ }^{60}$ It seems however, that when outbreaks of typhoid fever occurred, it seldom if ever reached truly epidemic proportions. In the 26 years up to 1939, seven outbreaks occurred in Pretoria, all of them milkborne. There were no waterborne outbreaks in that period and no outbreak comprised more than 30 cases. ${ }^{61}$

In Cape Town, Dr Shaddick Higgins, the Medical Health Officer of Health submitted a report reflecting 85 cases of typhoid fever in April and May 1943, mostly resulting from consumption of contaminated milk. ${ }^{62}$ Other causes reported by the Public Health Committee included excremental pollution of subsoil water from the Cape Flats, primitive, unsanitary pail latrines (some people had no latrines at all), and also from the flies that feasted on the manure from stables in parts of Cape Town. ${ }^{63}$ Higgins attributed these problems to poverty and the social degradation of populations that converged in the city. He warned that 'all human pollution has to be regarded as dangerous,' especially considering that in South Africa, the prevalence of typhoid fever was due to the use of polluted water supplies for drinking and domestic purposes. ${ }^{64}$ The greatest challenge was that as an insidious disease, it was difficult to point out visible signs from carriers; hence prevention became a matter of urgency.

The bold letters of a Rand Daily Mail headline on 15 August 1938 proclaimed typhoid fever by and large as the 'black man's disease' by stating, with reference to the town of Benoni, that 'Rural Natives Bring in Enteric'. ${ }^{65}$ The same newspaper echoed this view on 25 May 1939 with a headline stating with reference to the city of Pretoria: 'Carrier Problem in Eradicating Typhoid: Doctor Blames Small Townships and Native Hygiene'. ${ }^{66}$ The 1938 article, quoting an official report of the Benoni Public Health Department, who referred to typhoid fever as 'this disease of dirt' states:

'Due to infective organisms harbouring in dirt... enteritis will remain the most serious blot on the public health picture in Benoni until two problems have been solved among our non-European

60 NASAC, $1 / 4 / 7 / 6 / 1 / 1-1 / 4 / 7 / / 6 / 1 / 6$, - Public Health Committee Minutes, August 1939 July 1946.

61 Anon., "Carrier Problem in Eradicating Typhoid".

62 NASAC, 3/CT, 1/4/7/6/1/3, Report on the Outbreak of Enteric Fever in Cape Town, S. Higgins, 14 June 1943.

63 NASAC, 3/CT, 1/4/7/6/1/3, Report on the Outbreak of Enteric Fever in Cape Town, S. Higgins, 14 June 1943.

64 NASAC, 3/CT, 1/4/7/6/1/3, Report on the Outbreak of Enteric Fever in Cape Town, S. Higgins, 14 June 1943.

65 Anon., "Rural Natives Bring in Enteric".

66 Anon., "Carrier Problem in Eradicating Typhoid". 
population. The first is the provision of sanitary housing, which includes adequate kitchen and pantry facilities as well as a sufficient and easily available supply of water for domestic purposes. The second is the education of the people in the old rule that cleanliness is next to godliness, which many of the Bantu have forgotten since they left their rural kraals to dwell in city slums'. ${ }^{67}$

The 1939 article, quoting Pretoria Medical Health Officer, Dr H. Nelson, similarly blames the spread of typhoid fever on 'natives who have not the same appreciation of cleanliness and hygiene as the whites'. ${ }^{68}$ Both articles, however, blame the poor socio-economic position of black people for their vulnerability to typhoid fever absence of waterborne sewage, overcrowding, malnutrition and inaccessibility of basic health care. A similar view was held by the Red Cross, indicating that

typhoid fever attacks people of all races...owing to the unsanitary conditions under which natives often live the disease is common among them and they are a source of infection to the rest of the community. ${ }^{69}$

What the two newspaper articles did not point out was that socioeconomic class and race overlapped almost completely in South Africa, making typhoid fever 'the poor man's disease rather than simply 'the black man's disease'.

The Benoni Public Health Department blamed migrant black mine workers 'coming from all corners of Southern Africa', for bringing 'a considerable amount of enteric infection from the rural areas ${ }^{70}$ to Benoni. The Health Department contended that

(M)ine natives mirror the enteric position in the rural population and so long as the incidence of "carriers" in the country districts remains high so long will there be many unrecognised "carriers" entering employment in the mines. ${ }^{71}$

This influx of people from the rural areas certainly did not affect the mining sector only; other sectors of South African society, including the UDF, also drew workers from those areas. Nelson claimed, for example, that 'all the labour in connection with dairies and foodstuffs is done by natives'. ${ }^{72}$ Furthermore, as the Benoni Public Health Department correctly points out,

(T)hese men [the miners] come into the location [black residential

67 Anon., "Rural Natives Bring in Enteric".

68 Anon., "Carrier Problem in Eradicating Typhoid".

69 NASAC, 1/UTA, 6/1/17, 13/3/6 (old no, 13/8/3), South African Red Cross Society-Union Department of Public Health. This document was available at the end of the Second World War, 21 December 1945.

70 Anon., "Rural Natives Bring in Enteric".

71 Ibid.

72 Anon., "Carrier Problem in Eradicating Typhoid". 
area] and the township at week-ends and associate with the urban dwellers. ${ }^{73}$

To kill the health threat at its base, it was

of real importance... that the incidence of enteric fever on the mines should be reduced as rapidly as possible. ${ }^{74}$

In his analysis of typhoid fever in Pretoria over the 27 years up to 1939, which was in fact a thesis that he submitted for an M.D. degree in Dublin, Nelson came to the conclusion, as did the Benoni Public Health Department that the main cause of the occurrence of typhoid fever was the carrier. He too identified blacks as the principal carriers, stating that 'on several occasions the source of infection was traced to a newly employed native carrier handling foodstuffs or utensils' ${ }^{75}$

The same desperate socio-economic conditions that caused a comparatively high incidence of typhoid fever amongst black people also led to a much higher mortality rate among them than among white people. Of 144 cases of typhoid fever treated at the Isolation Hospital in Pretoria over a two-year period in the late 1930s, 18 (25,7 per cent) of the 70 blacks died, compared to only four $(5,4$ per cent) of the 74 whites. $^{76}$

As pointed out above, typhoid fever is to a large extent a preventable disease and in the case of Benoni, the incidence rate (all races) was reduced from 2,54 per thousand of the population in 1936 to 1,03 per thousand in 1937 through prophylactic measures. The incidence amongst Europeans had fallen to one-third of the 1936 rate, while the 'location native rate' had been 'considerably reduced', but the 'mine native rate' proved comparatively slow to fall.

A preventative programme at Van Ryn Deep near Benoni made it abundantly clear that the best results were obtained if strict attention was paid to sanitation in addition to inoculation. ${ }^{77}$ In the case of Pretoria, Nelson believed that the best way to combat the spread of typhoid fever was to immunise the entire population, but this was not practicable, so only contacts were inoculated. ${ }^{78}$ This was, of course, also the case in of the rest of the country.

Whenever certain conditions or individuals are perceived to be endangering the health of society at large, public authorities have an obligation to act preventatively. Since it was not possible to

73 Anon., "Rural Natives Bring in Enteric".

74 Ibid.

75 Anon., "Carrier Problem in Eradicating Typhoid".

76 Ibid.

77 Anon., "Rural Natives Bring in Enteric".

78 Anon., "Carrier Problem in Eradicating Typhoid". 
immunise the entire population and it was determined that the main cause of the occurrence of typhoid fever was the carrier, it follows logically that the alternative to an all-inclusive immunisation programme was to find and neutralise the carriers. ${ }^{79}$ Having identified black mine workers as the carriers, the Benoni Public Health Department consequently emphasised that the incidence of enteric fever on the mines should be reduced as rapidly as possible'. ${ }^{80}$

The South African military soon bought into the idea of finding and neutralising typhoid carriers. Carriers were sometimes found in the course of the examination (blood testing) of black people engaged in the handling of food in the kitchens and messes of the UDF. The normal procedure in such cases was to discharge such individuals or transfer them to other jobs. The problem was that those of them that were so-called 'trained kitchen boys' would often take their discharge and find employment elsewhere in the food industry. ${ }^{81}$ In order to neutralise that possible source of infection, the Deputy Assistant Director of Medical Services, UDF suggested to the Native Commissioner in June 1941 that

... the passes of boys who may not act as foodhandlers, be so endorsed, and that this endorsement be transferred to new passes when issued. ${ }^{82}$

No mention was made of identifying and dealing with white carriers, endorsing the notion that it was 'the black man's disease'.

The Secretary for Native Affairs, however, discarded the idea of endorsing the passes of carriers identified through blood testing. His argument was that it was futile since only 'a few' carriers of typhoid fever (approximately two per cent of those tested by the military authorities) where dealt with by the UDF, 'whilst hundreds of other cases never come to light. ${ }^{83}$ Furthermore, the Secretary for Native Affairs contended, if the 'positive' blood tests were not followed up with further, complicated tests, there was a possibility that people who were not actually carriers of the disease could be 'stigmatised' and if passes were to be endorsed accordingly, injustices might be created and the Department [could be] involved in legal actions'. ${ }^{84}$ Fear for the

79 Ibid.

80 Anon., "Rural Natives Bring in Enteric".

81 NASA, NTS 6716, 27/315, Deputy Assistant Director of Medical Services - Native Commissioner, 4 June 1941.

82 NASA, NTS 6716, 27/315, Deputy Assistant Director of Medical Services - Native Commissioner, 4 June 1941.

83 NASA, NTS 6716, 27/315, Secretary for Native Affairs - Native Commissioner, 17 July 1941.

84 NASA, NTS $6716,27 / 315$, Secretary for Native Affairs - Native Commissioner, 17 July 1941. 
infringement of human rights thus informed the Secretary for Native Affairs' decision to discard the proposed pass endorsement system.

Drastic and discriminatory as the military's proposed pass endorsement system would have been, it was not without precedent in public health authorities' dilemma in trying to protect the public's health against individual carriers of disease while at the same time preserving the civil liberties of such individuals. The most well-known example of this is probably the case of the Mary Mallon, alias 'Typhoid Mary', who was identified as a healthy carrier of typhoid fever in the USA in 1904 and detained for life to prevent her from endangering public health. It was calculated that she infected no less than $47-51$ people directly with the typhoid bacteria, three of whom died. This was, however, just the tip of the iceberg, as she infected scores of people indirectly as well. ${ }^{85}$

\section{The construction of the Berg River-Saldanha Bay water pipeline}

One of the many military projects on which black workers were employed inside the Union of South Africa was the construction of the Berg River-Saldanha Bay water pipeline in 1942/3. This project was in fact the culmination of the vision and dreams of theorists, planners, developers and others over no less than three centuries. European seafarers recognised Saldanha Bay as one of the best natural harbours in the world even before the Dutch refreshment station was established at the Cape in 1652. The British, when they occupied the Cape almost one and a half centuries after the Dutch arrival, saw great potential in Saldanha Bay as a naval base, but never exploited it. The principal reason for this lack of development was the absence of a sustainable supply of fresh water. The prospect of diverting water from the nearby Berg River to Saldanha Bay had been contemplated ever since the Dutch settlement, but only came to fruition in the mid-twentieth century when, during the Second World War, military necessity forced the Union government into action. Italy's entry into the Second World War in June 1940 made the Mediterranean

85 Mary Mallon was the first person in the United States of America to be recognised as a healthy carrier of typhoid fever and was identified as such during an epidemic that spread through parts of New York City in 1904. She worked as a cook in the homes of New York City's elite between 1900 and 1915, moving from household to household. Mary was eventually forcibly detained for life in a small bungalow at an isolation hospital on North Brother Island in the East River. (J.W. Leavitt, Typhoid Mary: Captive to the Public's Health (Beacon Press, Boston, 1996), pp xviixviii, 1-8, 14-21, 255; Encyclopædia Britannica, "Typhoid Mary", Encyclopaedia Britannica 2008 Ultimate Reference Suite (Encyclopædia Britannica, Chicago, 2009); Anon., "Mary Mallon, http://en.wikipedia.org/wiki/Mary Mallon, accessed 13 December 2007; J. Rosenberg, "Typhoid Mary", http://history1900s.about.com/ od/1900s/a/typhoidmary.htm, accessed 13 December 2007.) 
extremely unsafe for Allied shipping, with the result that Allied supply ships serving the Middle East theatre were compelled to sail around the Cape to the Red Sea. The tremendous increase in traffic along the South African coast completely saturated the Union ports, particularly Table Bay (Cape Town). The South African Government, in consultation with Great Britain, consequently decided in 1941 to build an additional port at Saldanha Bay to relief the pressure on Table Bay. ${ }^{86}$

Figure 1: The Berg River-Saldanha Bay water pipeline, 1942/ $1943 .{ }^{87}$

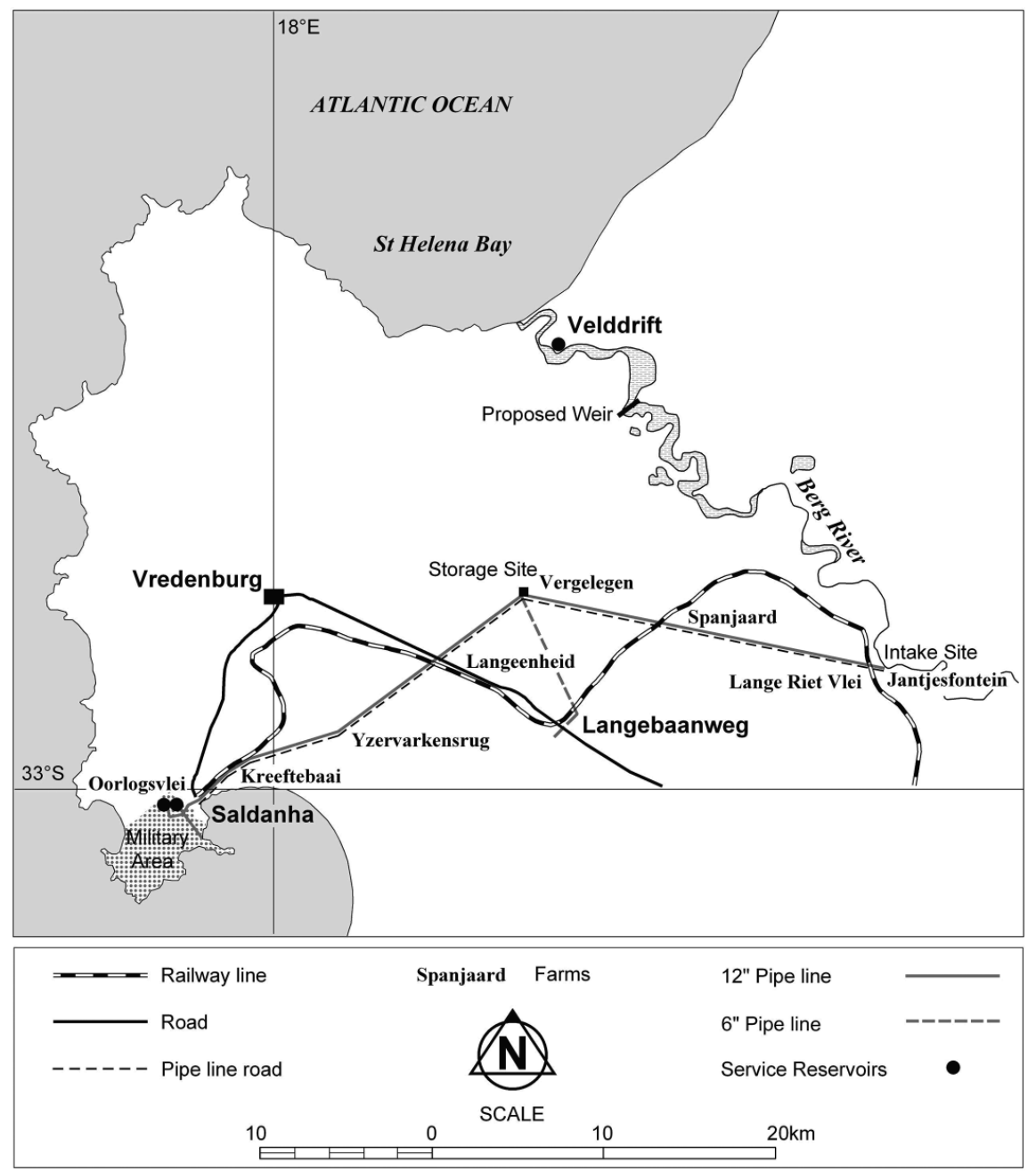

86 See G.E. Visser, J.A. Jacobs and H.A.P. Smit, "Water for Saldanha: War as an agent of change", Historia, Vol. 53, No 1, May 2008, pp. 130-61.

87 G.E. Visser, J.A. Jacobs and H.A.P. Smit, "Water for Saldanha: War as an Agent of Change", p. 145. 
The military activities at Saldanha put severe pressure on the town's meagre water supplies. This was bound to become even worse if Saldanha Bay became a convoy assembly point, as the British envisaged (and as had actually happened in January 1943), when an even larger number of ships would have had to be supplied with fresh water. The Union Government therefore, by June 1942, granted the Department of Defence permission and funding to lay a 55 kilometres $(\mathrm{km})$ long pipeline (see figure 1), interspaced with storage reservoirs at various points, from the Berg River to bring an estimated 4550000 litres (1) of fresh water per day to Saldanha Bay. ${ }^{88}$

No. 15 Field Company, South African Engineers Corps (eight officers and 85 men) under the command of Capt. J.M. Stacey, subsequently succeeded by Maj. W.R.F. Connell, was summoned from Sonderwater north of Pretoria to Saldanha to construct the Berg River water works, pipeline and reservoirs. The construction of the water works at the intake site and the commencement of the pipeline from that end were entrusted to No. 2 Section (one officer and 21 men) under Lt. G.J. M. Kirk (later succeeded by Capt. J.C.G. du Toit), who pitched camp at the Berg River intake site, about one and a half kilometres upstream from Berg River Station on the farm Jantjesfontein, on 11 August 1942. The remainder of No. 15 Field Company carried out various other engineer missions in the Saldanha Bay area, including constructing intermediate storage reservoirs along the course of the pipeline. ${ }^{89}$

Although a mechanical shovel was brought by train from Cape Town to Berg River Station to excavate the settling tanks and filter beds at the intake, most of the excavation work on the pipeline had to be done manually. A contingent of 49 black workers ('unattested black labourers') under a white overseer thus joined the engineer section at the Berg River intake site. The total number of black workers employed on the pipeline was initially 172 , but more workers started arriving towards the end of September, pushing their numbers up to 616 by 9 October..$^{90}$ Some of these black workers were recruited in the Transkei, whilst others were later taken on, inter alia, from the Langa Township on the outskirts of Cape Town. ${ }^{91}$ These predominantly black areas were prejudiced in terms of the prevalence of typhoid fever and the apparent 'indifference' of the public heath

88 G.E. Visser, J.A. Jacobs and H.A.P. Smit, "Water for Saldanha: War as an Agent of Change".

89 G.E. Visser, J.A. Jacobs and H.A.P. Smit, "Water for Saldanha: War as an Agent of Change".

90 South African National Defence Force Archives (hereafter SANDFA), WD 127, War Diary 15th Field Coy. SAEC, 1-31 October 1942, report by J.M. Stacy for week ended 9 October 1942.

91 NASA, NTS 9843, 56/408B, J.J. du Pre le Roux - Secretary for Public Health, 7 June 1943. 
authorities to the plight of blacks living there.

Dr G. H. Gunn, medical officer of Health Department in Durban wrote disparagingly in the Daily Dispatch of 1944 that East London's 'incidence of typhoid fever amongst non-European population' was at 900 per cent as compared to Pietermaritzburg which stood at 300 per cent by 1943. ${ }^{92}$ The East London Public Health authorities dismissed these figures and indicated that from 1938-1943, 103 cases were reported. ${ }^{93}$ Between 1940 and 1943, the Magistrate of Umtata, E.F. Owen, was notified regularly about incidence of between two to five cases monthly of the disease and advised to facilitate the 'cleaning up and disinfection of abode and surroundings' in his district. ${ }^{94}$ The Public Health Committee reports also referred to Langa Township frequently in connection with the occurrence of cases of typhoid fever.

The engineers surveyed and pegged the course of the pipeline between the Berg River and Saldanha Bay and pitched a number of intermediate camps at various intervals along the route in order to carry on with the construction work at several places simultaneously. The construction teams then commenced with the backbreaking excavation of the trench, the laying of the 305-mm (12-inch) piping and the construction of the water works and intermediate storage reservoirs under the blistering summer sun of the Western Cape. The mechanical shovel helped a lot, but it broke down frequently, forcing the construction teams to fall back on manual labour alone. The initial acute shortage of workers slowed the construction down, but the construction teams made reasonable progress from late September when the additional workers started joining the construction teams. ${ }^{95}$

On 14 October 1942 Capt. J.M. Stacey, commanding officer of No. 15 Field Company, SAEC, received instructions from the Chief Fortress Engineer, Cape Fortress to suspend all non-essential works and to speed up the work on the Saldanha Bay water scheme. No. 1 Section of No. 15 Field Company, SAEC, was subsequently transferred from Saldanha Bay to the intake site to increase the workforce. Despite the fact that his black workforce had risen to 729 - inter alia through the recruitment of 94 men in the black township of Langa near Cape Town on 5 November - Maj. Connell reported that a shortage of workers was hampering his progress considerably when he had to negotiate a

92 NASAC, 3/ELN, 2004, Outbreak of Typhoid Fever at Duncan Village, Typhus Epidemic in the Transkei, 11 April 1944.

93 Ibid.

94 NASAC, 1/UTA, 6/1/17, 13/3/6, Outbreak of Typhoid in Gwaqana, Manqondo Location, Mqanduli, Zueque Location, Transkei, August 1943.

95 G.E. Visser, J.A. Jacobs and H.A.P. Smit, "Water for Saldanha: War as an agent of change". 
limestone layer over a distance of almost one kilometre north of the main road to Vredenburg in early November. At one stage, the construction teams had to work 24-hour shifts with the only two jackhammers available. By the end of November, he consequently asked for an additional 200 workers to speed up the excavation work and complained that the non-delivery of more jackhammers was delaying his work. More workers were indeed recruited during the next month or two because of his plea, bringing the total to $1200^{96}$ by May/June 1943. Connell succeeded in making good progress despite all the difficulties and the first water from the Berg River pipeline reached Saldanha Bay on 7 February 1943. ${ }^{97}$

\section{The outbreak of typhoid fever at the Berg River intake site}

The accommodation of the black workers at these camps illustrated how South Africa's racial policies not only barred black people from enlisting for combat service, but also exposed them to adverse conditions in the workplace, particularly with regard to living conditions. At the intake site on the Berg River, the whites lived comfortably in the farm buildings on the site. Elsewhere wartime pressure on resources rendered the accommodation of the engineers somewhat less than spectacular. According to an entry in No. 15 Field Company's war diary on 13 September 1942, they constructed officers' quarters, a hut for the Company Sergeant-major and a bungalow for the men at Saldanha Bay from 'aeroplane packing cases'. ${ }^{98}$ The black workers, in sharp contrast, were housed in rudimentary inverted $\mathrm{V}$-shaped galvanised corrugated iron shelters or lean-tos, $2,75 \times 2,5$ metres (9 ft. $\times 8 \mathrm{ft}$.) in size, without any ventilation. With room to house no more than four men with any comfort, it was customary to put six persons in such a shelter. Acting Native Commissioner, A.A. Burge, expressed doubt that the military authorities had consulted a medical officer when these buildings were put up. ${ }^{99}$

By May 1943, there were 380 black workers at the intake site on the Berg River, with 64 shelters erected for them. Though that was sufficient to accommodate the men at the customary ratio of six per shelter, Burge found no less than nine living in one shelter, whether

96 NASA, NTS 9843, 56/408B, J.J. du Pre le Roux - Secretary for Public Health, 7 June 1943.

97 G.E. Visser, J.A. Jacobs and H.A.P. Smit, "Water for Saldanha: War as an agent of change".

98 SANDFA, WD 127, War Diary 15th Field Coy. SAEC, 13 September 1943.

99 NASA, NTS 9843, 56/408B, A.A. Burge - Director of Native Labour, 2 June 1943; ibid., anon., handwritten note on letter, 17 June 1943. 
by choice or force. ${ }^{100}$ Both summer heat and winter cold rendered this primitive accommodation unpleasant and inconvenient, but, more seriously, these overcrowded living conditions were not conducive to good health, particularly with a view to the threat of typhoid fever. The workers obtained their drinking water from the river, but it was treated with ammonia and chlorine by means of a portable unit before consumption. They were, however, washing and swimming in the polluted water on a daily basis. ${ }^{101}$ These activities were indeed creating a time bomb, since the Cape Circle Engineer, E. Fincham, reported as early as February 1938 that the Public Health Department had warned him

not to drink the [Berg] river water or bathe in it as it was "extremely dangerous"... [since] enteric [fever] is rife from Wellington right to the sea... [and the] Berg River water is now "a menace to public health". ${ }^{102}$

On 25 March 1938 the acting Cape Circle Engineer, furthermore, reported that typhoid fever was 'almost endemic'103 at the little settlement of Velddrift near the Berg River mouth with its 1600 European and 300 'coloured' inhabitants and suggested that the Public Health Department, the local Divisional Council and other government departments concerned should pay attention to this health threat. ${ }^{104}$

Normally the military authorities paid due attention to health issues based upon medical intelligence that preceded the deployment of forces. The $61^{\text {st }}$ Tunnelling Company, the black unit attached to the South African Engineer Corps (SAEC) to serve in the tunnel construction on the Haifa-Beirut-Tripoli railway and on the Kasmieh (Lebanon) irrigation scheme, for example, though exposed to hazardous conditions, benefited from an hygiene section that provided medical support to all personnel, including civilian labourers. ${ }^{105}$ Surprisingly the military authorities did not follow up the information on the prevalence of typhoid fever on the Berg River and put no proper medical countermeasures in place when the construction of the pipeline commenced. The Department of Native Affairs, who was primarily responsible for the welfare of all black

100 Ibid.

101 NASA, NTS 9843, 56/408B, J.J. du Pre le Roux - Secretary for Public Health, 7 June 1943.

102 SANDFA, DC 3395, DC2305/51/2 I, Circle Engineer, Cape Circle - Director of Irrigation, 24 February 1938.

103 SANDFA, DC 3395, DC2305/51/2, I, Acting Circle Engineer, Cape Circle Director of Irrigation, 25 March 1938.

104 Ibid.

105 SANDFA, UWH (Civil) 166, Narep-Unfo 21, SAEC: 61 Tunnelling Coy, 19411944 (Syria, Lebanon, Italy), August 1943. 
workers in government employ, did not see to it that the military authorities make adequate arrangements with regard to the health care of the workers at the Berg River camp. The military authorities did not test the cooks preparing their meals in the on-site camp kitchen to determine if they were carriers of typhoid fever or other diseases. The district surgeon at Vredenburg, Dr C. Rauch, and the medical officer at Saldanha, one Capt Comay, furthermore, carried out the examination and general medical care of the workers on a voluntary basis. This was an unsatisfactory arrangement with a view to the fact that the state was contract-bound to provide free medical services to their unattested black workers. Furthermore, the UDF informed the workers recruited from Langa that they would get free food and accommodation in addition to their wages, but no mention was made of medical treatment. ${ }^{106}$

The riparian dwellers, who were more sensitive to the health risk on their doorstep than the military authorities, were not happy with the presence and behaviour of the construction workers at the Berg River intake site at Jantjesfontein. On 20 January 1943 Hein Wicht, owner of the adjoining farm, warned the Secretary for Defence that there was 'a serious danger of the river becoming contaminated... [since] large numbers of natives were bathing and washing clothes in the river... [and] traces of crude sewage [was found] stranded on my frontage. ${ }^{107}$ Given Fincham's above-mentioned report of 1938, chances are that the river was already contaminated when the workers arrived there. Be that as it may, the Acting Director of Fortifications and Coastal Works in Cape Town promised that the bathing and washing would be stopped. A concerned and annoyed Wicht, however, complained on 7 May that these activities were continuing. ${ }^{108}$

On 13 May, less than a week after Wicht's second letter of complaint, six of the workers at the intake site reported sick, whilst a seventh who also fell ill proceeded directly to Cape Town. All of them were diagnosed with typhoid fever, as was an eighth individual who fell ill on 22 May. One of the original seven was admitted to Malmesbury Hospital, while two were sent to the City Infectious Diseases Hospital in Cape Town. The rest were treated in a sickbay at the camp, where the district surgeon and a medical orderly attended to them. This intervention saved six of the eight, but two unfortunately did not

106 NASA, NTS 9843, 56/408B, J.J. du Pre le Roux - Secretary for Public Health, 7 June 1943.

107 SANDFA, DC 3395, DC2305/51/2 I, H. Wicht - Secretary for Defence, 20 January 1943.

108 SANDFA, DC 3395, DC2305/51/2 I, H. Wicht - Secretary for Defence, 7 May 1943. 
survive. Tests indicated that the workers' drinking water was not contaminated and the health authorities concluded that the workers were probably infected by swimming and washing in the river. The health authorities suspected that the infection occurred during the Easter weekend at the end of April when there was more opportunity for swimming and when there were consequently more people in the water. ${ }^{109}$

Martin Melck, the riparian farmer on whose property the pumping station was built, wrote on 26 May 1943 that he had learned with 'great alarm' of the 'highly dangerous and infectious disease... [that had] broken out among the natives' and expressed the hope 'that every step is being taken to prevent [the] infection spreading'. ${ }^{110} \mathrm{He}$ complained, as he had done before, according to his letter, about

the slackness of control of these natives...[who] are always found all over my property and also here at the main homestead after dark which is very much against my wishes and requests to the O.C. [Officer Commanding] in charge. ${ }^{111}$

He furthermore stated that the workers 'still are not compelled to use a proper lavatory but litter the veld with their offal' and stated that he

'much fear[ed] the safety of... [his] "boys" as they have to use the river water especially in this very much delayed rainy season'. ${ }^{112}$

Part of Melck and his fellow farmers' dissatisfaction and annoyance with the construction workers perhaps resulted from prejudice. The Magistrate at the nearby town of Hopefield remarked in a letter to the Secretary for Native Affairs in March 1944 when farmers in that area complained about 'a large number of unemployed natives lying about on... [their] farms' that

'farmers and others... in this part of the country are not used to natives and do not understand them, but insist on regarding them all as thieves and murderers'. ${ }^{113}$

The Acting Director of Fortifications and Coastal Works claimed, in response to Melck's complaints, to have given 'strict instructions... to the parties concerned to rectify this matter, but that owing to... the breakdown of certain pumping equipment it is evident that the natives

109 NASA, NTS 9843, 56/408B, J.J. du Pre le Roux - Secretary for Public Health, 7 June 1943.

110 SANDFA, QMG (Gp 19) 155, DC(E)671/2/101 I, M. Melck - Secretary for Defence, 26 May 1943.

111 Ibid.

112 Ibid.

113 NASA, NTS 9843, 56/408B, Magistrate Hopefield - Secretary for Native Affairs, 31 March 1944. 
again went down to bathe and wash in the river'. ${ }^{114}$ After they had repaired the pumping equipment, the military authorities commenced putting up a fence to prevent what they called 'a recurrence of the nuisance'. 115

Having received a report from the district surgeon, Dr Rauch, about the eight men that came down with typhoid fever at the Berg River intake site, Dr J.J. du Pre le Roux of the Union Health Department in Cape Town, accompanied by military hygiene officer Maj. R.E. Meaker and Acting Native Commissioner, A.A. Burge, rushed to the scene

in view of the fact that the water from this source was being supplied to shipping at Saldanha Bay. ${ }^{116}$

The main concern thus seems to have been not for the good health of the workers in the first place, but rather about preventing contamination of the water supply to Saldanha Bay to avert possible infection of the thousands of soldiers, sailors and civilian personnel on board the Allied ships replenishing their water supply at Saldanha. The Berg river water was, of course, treated with chlorine at the intake at Jantjesfontein before it entered the pipeline to Saldanha Bay. A sample of the main water supply taken at Saldanha after the outbreak confirmed, fortunately, that the water in the pipeline was not contaminated. The public health authorities at the same time, rather belatedly, made arrangements for the main water supply to be tested on a weekly basis henceforth. ${ }^{117}$

Acting Native Commissioner A. A. Burge reported the primitive, overcrowded living conditions of the workers at the intake site to the Director of Native Labour in Johannesburg as he "may wish to take the matter up with the Military Authorities'.118 The latter forwarded Burge's letter to the Secretary for Native Affairs in Pretoria for 'any action you may consider necessary'. ${ }^{119}$ The Secretary for Native Affairs expressed concern that there was 'another much bigger camp in Saldanha where numbers are growing... [where] the housing should also be watched'. ${ }^{120}$ He suggested that all 'native camps' in the

114 SANDFA, DC 3395, DC2305/51/2 I, Acting Director of Fortifications and Coastal Works (Cape) - Secretary for Defence, 24 May 1943.

115 Ibid.

116 NASA, NTS 9843, 56/408B, J.J. du Pre le Roux - Secretary for Public Health, 7 June 1943.

117 Ibid.

118 NASA, NTS 9843, 56/408B, A.A. Burge - Director of Native Labour, 2 June 1943.

119 NASA, NTS 9843, 56/408B, Acting Director of Native Labour - Secretary for

Native Affairs, 14 June 1943.

$120 \mathrm{Ibid}$, anon. handwritten note on letter. 
Saldanha area should be inspected by a hygiene officer. ${ }^{121}$ Besides the total of 1200 workers employed on the pipeline, a further 800 blacks were employed by civilian contractors working for the Department of Defence at Saldanha Bay, ${ }^{122}$ which brought the total number of black workers in the Saldanha area to about 2000 and increased the threat of an outbreak of typhoid fever.

The military and public health authorities succeeded in containing the outbreak of typhoid fever at the intake at Jantjesfontein and preventing it from reaching epidemic proportions. The Acting Director of Fortifications and Coastal Works reported to the Secretary for Defence on 9 June 1943 that

(T)he position is under control and... all natives have been inoculated [with typhoid endotozoid ${ }^{123}$ ] and any recruits coming to the area are also inoculated'. ${ }^{24}$

Mother Nature had in the meantime also made a contribution to remedy the health situation, for by early June 'the very much delayed rainy season'125 had finally arrived and the Berg River was 'flowing fairly rapidly ${ }^{126}$, which reduced the risk of contamination.

Though there were no further occurrences of typhoid fever at the Berg River camp, many more cases were reported in Cape Town (the total for the period September 1943-August 1945 was 475 cases), ${ }^{127}$ which was of great concern to the UDF since they recruited some of their workers in the Saldanha Bay area from the black residential areas around the city. ${ }^{128}$ Apart from new recruits coming in, these workers presumably went home during weekends and on vacation leave from time to time, which created the opportunity for infection and made protective inoculation of both serving workers and new arrivals imperative. In addition, there was also an influx of black people from Cape Town into Saldanha Bay as the construction work in the Cape Peninsula was completed and workers made their way to Saldanha to find new employment and were taken on by contractors when they

121 Ibid.

122 NASA, NTS 9843, 56/408B, J.J. du Pre le Roux - Secretary for Public Health, 7 June 1943.

123 Ibid.

124 SANDFA, DC 3395, DC2305/51/2 I, Acting Director of Fortifications and Coastal Works (Cape) - Secretary for Defence, 9 June 1943.

125 SANDFA, QMG (Gp 19) 155, DC(E)671/2/101 I, M. Melck - Secretary for Defence, 26 May 1943.

126 SANDFA, QMG (Gp 19) 155, DC(E)671/2/101 I, Acting Director of Fortifications and Coastal Works (Cape) - Secretary for Defence, 9 June 1943.

127 NASAC, $3 /$ CT, $1 / 4 / 7 / 6 / 1 / 3-3 / C T, 1 / 4 / 7 / / 6 / 1 / 5$, Monthly Health Reports, Public Health Committee Minutes, September 1943-August 1945.

128 SANDFA, DC 3395, DC2305/51/2 I, Acting Director of Fortifications and Coastal Works (Cape) - Secretary for Defence, 9 June 1943. 
required additional labour. ${ }^{129}$

The Acting Director of Fortifications and Coastal Works in Cape Town assured the Secretary for Defence shortly after the outbreak of typhoid fever at the Berg River pumping station that 'suitable latrines and ablutions are in existence in their [the workers'] camp area, and strict instructions against fouling of the bush and washing in the river are being complied with'. ${ }^{130}$

He stated, in response to Melck's above-mentioned complaints, that 'every endeavour is being made to control these natives' ${ }^{131}$ but pointed out that it was very difficult to prevent them from wandering onto adjoining properties after working hours. ${ }^{132}$

The voluntary medical services rendered to the black workers involved in the construction of the Berg River pipeline by the district surgeon, Dr C. Rauch, and the medical officer at Saldanha, Capt Comay, was in the meantime discontinued at the end of May 1943. ${ }^{133}$ The Acting Director of Native Labour, who appreciated that standard conditions with regard to accommodation could not always be maintained in wartime, stressed that 'the same latitude should not be permitted in respect of medical attention'134 and urged the military authorities to make proper arrangements in that regard. In early July 1943 the Secretary for Native Affairs, through the Acting Native Commissioner, stressed to the Director of Fortifications in Cape Town that the accommodation of the black workers in the Saldanha Bay area was 'by no means satisfactory' due to overcrowding, a lack of proper ventilation and inadequate provision for ablution and pushed for appropriate steps to be taken to remedy the situation. ${ }^{135}$

The military engineers soon after wrapped up construction of the pipeline, but hundreds of black workers were still employed in Saldanha Bay and at Langebaan Road, where an aerodrome was being built. The military authorities now assumed overall responsibility for the accommodation and medical arrangements of all black

129 NASA, NTS 9843, 56/408B, J.J. du Pre le Roux - Secretary for Public Health, 7 June 1943.

130 SANDFA, DC 3395, DC2305/51/2 I, Acting Director of Fortifications and Coastal Works (Cape) - Secretary for Defence, 9 June 1943.

131 SANDFA, DC 3395, DC2305/51/2 I, Acting Director of Fortifications and Coastal Works (Cape) - Secretary for Defence, 9 June 1943.

132 Ibid.

133 NASA, NTS 9843, 56/408B, J.J. du Pre le Roux - Secretary for Public Health, 7 June 1943.

134 NASA, NTS 9843, 56/408B, Acting Director of Native Labour - Secretary for Native Affairs, 18 June 1943.

135 NASA, NTS 9843, 56/408B, Acting Native Commissioner - Director of Fortifications, 6 July 1943. 
workers, both those in the employ of the UDF and those working for contractors engaged in construction work for the UDF in the Saldanha Bay area and tightened up these services effectively. ${ }^{136}$ With the end of the Second World War in 1945 the wartime military activities gradually died down, most of the military personnel and black workers who had flocked to the Saldanha Bay area during the war departed and the wartime health challenges posed by the influx of people, overcrowding and the saturation of social services disappeared.

\section{Conclusion}

Racial discrimination embedded in the South African Defence Act and limited employment opportunities forced thousands of black men into the service of the UDF as civilian workers during the Second World War. These workers were vulnerable to health threats such as typhoid fever due to their poor socio-economic background and the unsatisfactory living conditions to which they were subjected in the work situation under wartime pressure. Negligence and sloppy health management on the part of the UDF and the public health authorities aggravated this. The threat of typhoid fever on the Berg River was well-known to them when the military engineers commenced the construction of the Berg River pipeline, yet they failed to take proper precautions against possible infections. Even when the riparian dwellers warned the military authorities of the health risk created by the large numbers of workers bathing and washing their clothes in the river and the presence of crude sewage in the river, they took no effective protective steps.

The subsequent outbreak of typhoid fever could potentially have reached epidemic proportions, threatening not only the life of hundreds of black workers along the Berg River pipeline, but also the life of thousands of soldiers, sailors and others in Saldanha Bay and on the large number of ships replenishing their water supplies in the Bay. From that perspective, the sloppiness of the military authorities with regard to hygiene and health care on the Berg River could theoretically have dealt the Allied war effort a serious blow. Fortunately, the outbreak was contained through the belated introduction of precautionary inoculation and a potential disaster was averted.

Appropriate medical intelligence normally precedes the deployment of armed forces to reduce the risks of contracting and spreading deadly

136 NASA, NTS 9843, 56/408B, Acting Director Medical Services Cape FortressDeputy Chief Health Officer, 14 November 1943. 
diseases. However, the outbreak of typhoid fever at the Berg River intake site proved that even an abundance of prior knowledge and early warning do not always translate into appropriate action on the part of the controlling authorities. The potentially disastrous situation, from both a health and an operational perspective, created through negligence on the Berg River during the Second World War should serve as a warning to the South African National Defence Force when deploying on peace support operations on the African continent: HIV/Aids might be the number one killer disease of our day, but typhoid fever, though defeated in medical terms, will rear its deadly head whenever preventative measures are neglected. 